\title{
Commercial Light Water Reactor Irradiated Hardware Waste Stream
}

by

D. J. Adamson

Westinghouse Savannah River Company

Savannah River Site

Aiken, South Carolina 29808

DOE Contract No. DE-AC09-96SR18500

This paper was prepared in connection with work done under the above contract number with the U.S. Department of Energy. By acceptance of this paper, the publisher and/or recipient acknowledges the U. S. Government's right to retain a nonexclusive, royalty-free license in and to any copyright covering this paper, along with the right to reproduce and to authorize others to reproduce all or part of the copyrighted paper. 


\section{DISCLAIMER}

This report was prepared as an account of work sponsored by an agency of the United States Government. Neither the United States Government nor any agency thereof, nor any of their employees, make any warranty, express or implied, or assumes any legal liability or responsibility for the accuracy, completeness, or usefulness of any information, apparatus, product, or process disclosed, or represents that its use would not infringe privately owned rights. Reference herein to any specific commercial product, process, or service by trade name, trademark, manufacturer, or otherwise does not necessarily constitute or imply its endorsement, recommendation, or favoring by the United States Government or any agency thereof. The views and opinions of authors expressed herein do not necessarily state or reflect those of the United States Government or any agency thereof. 


\section{DISCLAIMER}

Portions of this document may be illegible in electronic image products. Images are produced from the best available original document. 
EES

ENGINEERED EQUIPMENT \& SYSTEMS

WSRC-TR-98-00202

KEYWORDS:

CLWR

Tritium Production

LTA

Irradiated Hardware

Waste

Retention: Permanent

Tracking No. 10500

NI-434-89-8-7.b(1)(b)

\section{COMMERCIAL LIGHT WATER REACTOR \\ IRRADIATED HARDWARE WASTE STREAM (U)}

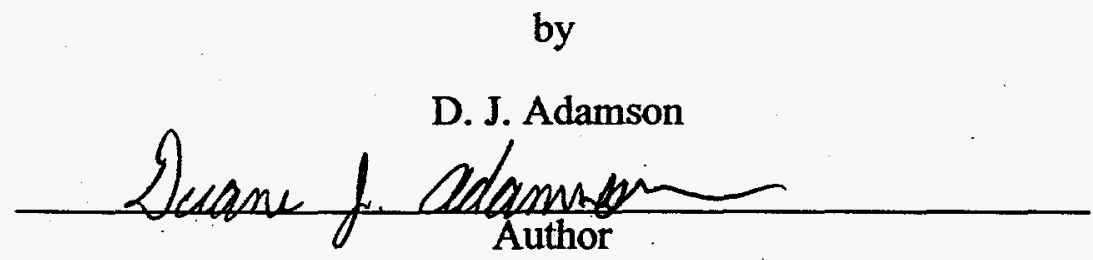

ISSUED: June, 1998

SRTC SAVANNAH RIVER TECHNOLOGY CENTER, AIKEN, SC 29808

Westinghouse Savannah River Company

Prepared for the U.S. Department of Energy under

Contract DE-AC09-96SR18500 
Document: WSRC-TR-98-00202

Title: $\quad$ COMMERCIAL LIGHT WATER REACTOR

IRRADIATED HARDWARE WASTE STREAM (U)

Approvals

duape d. Adamenn $\quad 6 / 25 / 98$

D.J. Adamsón, Author Date:

Atotes

M.J. Ades, SWD Reviewer

$6 / 25 / 98$

Date:

Stocha 1 Houst

S.T. Hargett, Technical Reviewer

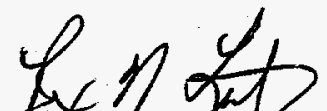

R. N. Latz, Rosponsible Manager

Before

B. C. Rogers, Level 3 Manager
$6-29-48$

Date:

$6-29-98$
$6 / 30 / 98$

Date: 


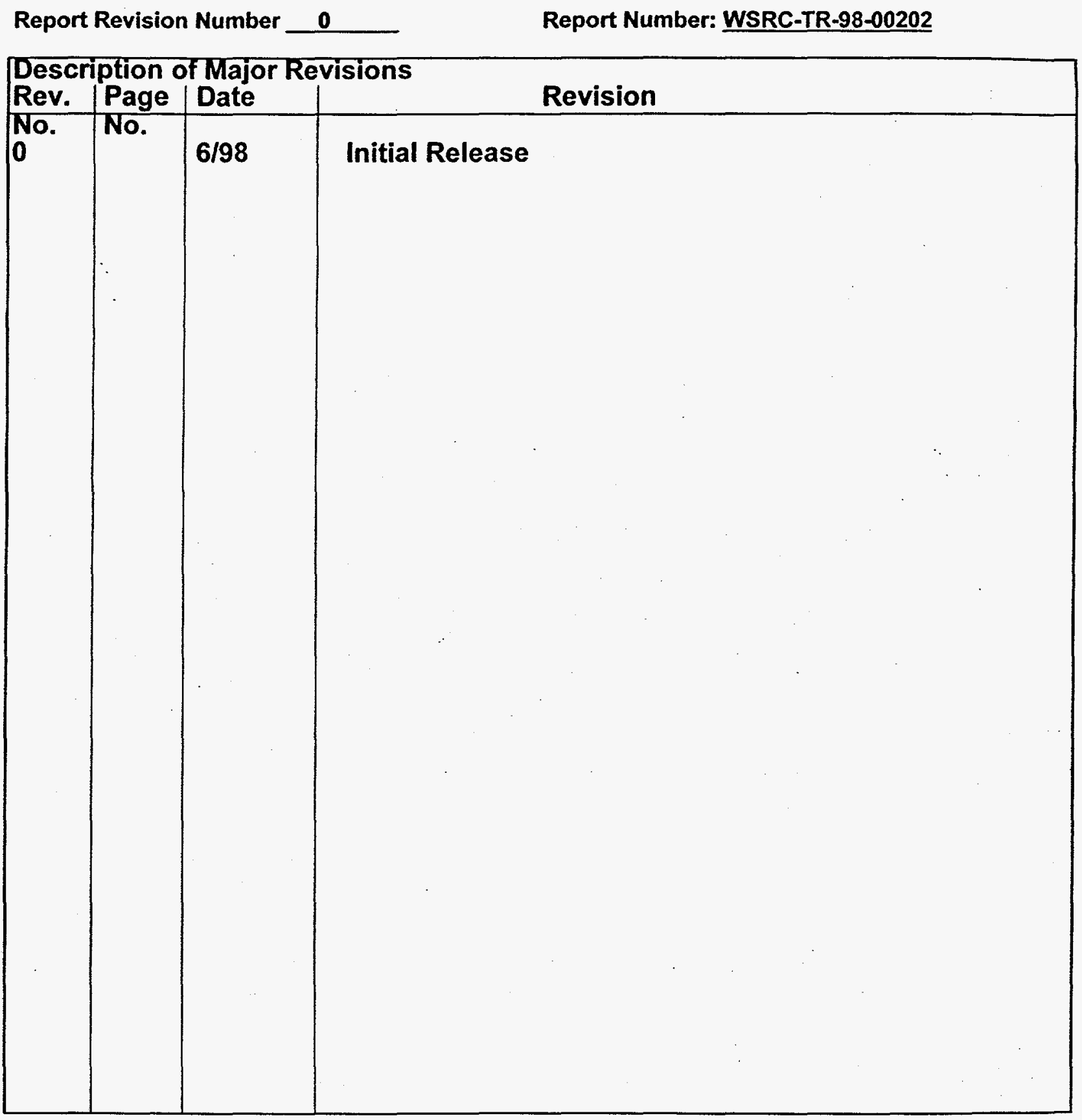




\section{Executive Summary}

The Commercial Light Water Reactor (CLWR) Production of Tritium is one of two options being investigated by the DOE for producing tritium, an essential element of our nation's nuclear stockpile. For the CLWR Program, tritium producing burnable absorber rods (TPBARs) will be attached to a baseplate assembly with thimble plugs as shown Figure 1. The TPBAR assembly will be placed in a CLWR for tritium formation through irradiation. From this process, two waste streams of the irradiated hardware will be generated. The first is attributable to the Lead Test Assemblies (LTA), a demonstration of the CLWR process, and the second is the consequence of irradiating production assemblies. The two waste streams only include the baseplate/thimble plug assembly with the TPBARs removed.

The irradiated hardware waste from the CLWR program will not introduce or process materials that could lead to criticality issues and there will be no generation of high level waste from processing the assemblies. ${ }^{1}$ The waste meets the waste acceptance criteria (WAC) of the 1S Manual for disposal in the E-Area Intermediate Level Tritium Vaults (ILTV) at SRS's Solid Waste Division. The waste will only have trace quantities of tritium and the radiological concentrations are below the limit of the WAC of the 1S Manual.

The average unshielded dose rate from one LTA baseplate/thimble plug assembly is $13,000 \mathrm{rem} / \mathrm{hr} @ 5 \mathrm{~cm}$ and $1,400 \mathrm{rem} / \mathrm{hr} @ 30 \mathrm{~cm}$. The average dose rate of one production baseplate/thimble plug assembly unshielded is 6,800 rem/hr@ $5 \mathrm{~cm}$ and $790 \mathrm{rem} / \mathrm{hr} @ 30 \mathrm{~cm} .^{2}$ Cobalt-60 is the principal contributor of the source term for the baseplate/thimble plug assembly. The average cobalt concentration is estimated to be 63 Ci/baseplate. ${ }^{3}$

The LTA irradiated hardware (waste) will be created during a one time CLWR research demonstration. The total volume of the four waste assemblies is $1.88 \mathrm{ft}^{3}$. The total production volume of waste per year is $117.5 \mathrm{ft}^{3}$. The calculated volumes for the LTA and production waste assumes worst case where the baseplate/thimble plug assembly will not be disassembled and does not include disposal containers. The CLWR Program may need to investigate methods of waste minimization of the irradiated hardware since the space is limited in the ILTV. The disposal volume of the waste stream could be reduced if the thimble plugs and the upper head injection cup are disassembled from the baseplate. 


\section{Introduction}

The Packaging and Transportation Group in the Engineering Development Section of the Savannah River Technical Center (SRTC) was assigned with this portion of the Commercial Light Waste Reactor (CLWR) Program Transportation task. The irradiated targets and waste for both the research demonstration and production process will require either roadway or rail transportation from the reactor(s). This CLWR Irradiated Hardware Waste Stream Document identifies the waste streams of the irradiated hardware of the CLWR Program. This document is applicable to the waste (irradiated hardware) generated by the irradiating reactor(s). Wastes generated by the CLWRTritium Extraction Facility are covered in document M-TRT-H-00006. ${ }^{4}$

For the CLWR Program, tritium producing burnable absorber rods (TPBARs) will be attached to a baseplate assembly with thimble plugs as shown Figure 1. The TPBARs are fabricated using zircaloy, lithium aluminate, nickel and stainless steel. Formation of tritium will occur on the inner diameter of the TPBARs during irradiation. Two waste streams of irradiated hardware will be generated during the CLWR program, the Lead Test Assemblies (LTA) and the production TPBAR Assemblies. There are a total of four (4) LTAs, each consisting of, one baseplate, 16 thimble plugs and 8 TPBARs undergoing irradiation at Watts Bar Nuclear Plant. During the irradiation process, the LTA baseplate assembly and thimble plugs will become radioactive as a result of neutron activation. The irradiated metal will emit a spectrum of photons from the radioactive decay of the activation products. Therefore, the irradiated metal will be categorized as low level waste. The LTAs are scheduled to be shipped to Argonne National Lab West (ANL-W) at Idaho National Engineering Laboratory. (INEL). The thirty-two TPBARs will undergo post irradiation examination at ANL-W and Pacific Northwest National Lab (PNNL) during 1999. The TPBARs are not scheduled for shipment to the Tritium Extraction Facility (TEF) for processing. However, disposal of the low level waste is being planned for SRS.

The CLWR production program will irradiate approximately 4,000 TPBARs per year to meet the DOE tritium goal. With the expected average of 16 TPBARs per assembly, 250 baseplate/thimble plug assemblies will be irradiated per year. In order for the tritium to be extracted, the TPBARs will be removed from the baseplate at the reactor(s) and shipped to TEF at SRS. The irradiated hardware waste will be shipped separately to SRS for disposal.

The waste from both the LTA demonstration and production are proposed to be disposed of in the E-Area Intermediate Level Tritium Vaults (ILTV) or in the future Low Level Waste (LLW) Disposal Facility located at the Solid Waste Division (SWD). Waste will be transported in approved disposal containers and certified transportation casks.

For the CLWR LLW to be disposed of in the E-Area ILTV at SRS, the waste and the disposal container must meet the requirements of the Waste Acceptance Criteria (WAC) 
Figure 1. CLWR Irradiated Hardware Waste Assembly

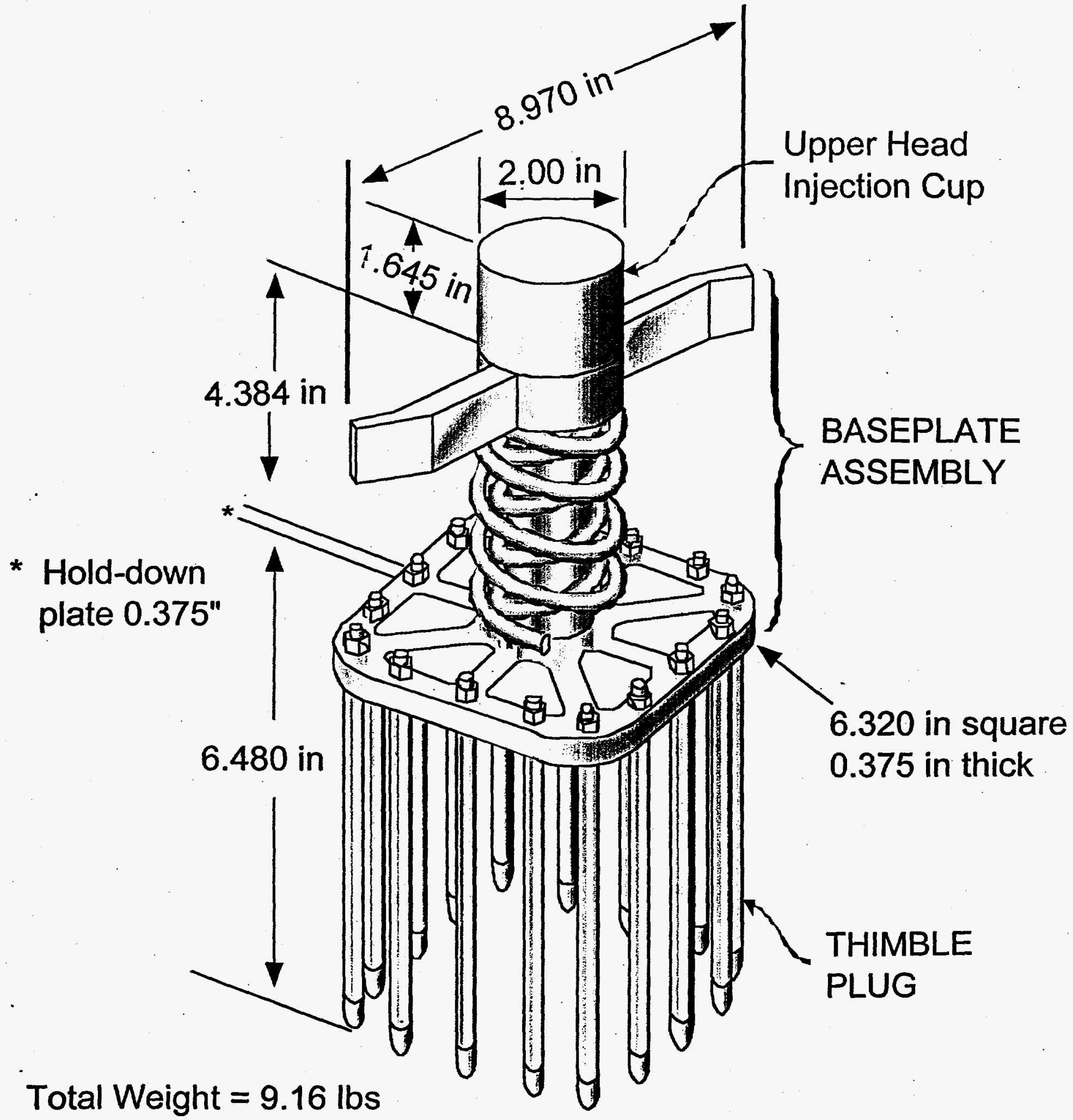

Material : stainless steel

Reference: 5 
of the WSRC 1S Manual. Alternatively if a WAC of the 1S Manual cannot be met, a deviation per the 1S Manual will be applied for from the SWD.

\section{Discussion}

Below are assumptions that were made to determine the waste streams for both the demonstration and production phases of the CLWR Program.

- TPBARs will be removed from the baseplate assembly before shipment to SRS

- Baseplate will not be disassembled and thimble plugs will remain connected as shown in Figure 1.

- The waste assemblies for both the LTA and production assemblies are constructed of stainless steel.

- The radionuclide concentrations of an irradiated LTA and production baseplate assembly and thimble plugs are the same.

- LTA irradiated hardware waste will be packaged at ANL-W and shipped to SRS for disposal at the E-Area ILTV.

- Production irradiated hardware waste will be packaged at the reactor(s) and shipped to SRS for disposal at the E-Area ILTV.

- The LTA will have sixteen (16) thimble plugs per baseplate.

- The production waste will have an average of eight (8) thimble plugs per baseplate.

The radionuclide concentrations of an irradiated LTA holddown assembly and the thimble plugs were estimated by PNNL and documented in TTQP-1-084. ${ }^{6}$ This information was used in the analysis of the source term using the ORIGEN2 code (RSIC 1996). QAD-CGGP computer code was used to calculate dose rates and shielding analyses. ${ }^{2}$ The dose rate calculations assume that the radionuclide concentrations of an irradiated LTA and production baseplate/thimble plug assembly are the same. The only difference in the two models used for the input to the code is the number of thimble plugs attached to the baseplate.

The baseplate/thimble plug has an estimated actual material volume of $5.17 \times 10^{-4} \mathrm{~m}^{3}$ $\left(0.018 \mathrm{ft}^{3}\right)^{7}$. Assuming a geometry of a cylinder for the baseplate/thimble plug assembly as shown in Figure 1, each assembly will occupy a space of $0.0133 \mathrm{~m}^{3}\left(0.47 \mathrm{ft}^{3}\right)$ inside the disposal container. The total disposal volume for the four LTAs is then $0.053 \mathrm{~m}^{3}$ $\left(1.88 \mathrm{ft}^{3}\right)$. The total mass of one LTA baseplate/thimble plug assembly is $4,156.5$ grams $(9.16 \mathrm{lbs} .)^{6}$ and $3,392.9$ grams $(7.47 \mathrm{lbs}$.) for the production waste assembly. The baseplate/thimble plug assembly has a height of $12.884 "$ and a diameter of $8.970 "{ }^{5}{ }^{5}$

Because the production reactor has not been chosen, the precise weights and dimensions of the production baseplate assemblies are not known. Therefore, dimensions of the productions assemblies are assumed to be the same as the LTAs. Each production assembly will have a volume of $0.0133 \mathrm{~m}^{3}\left(0.47 \mathrm{ft}^{3}\right)$ and a mass of 3392.9 grams $(7.47$ 
lbs.). The total volume of production waste per year is $250 \times 0.0133 \mathrm{~m}^{3}=3.3 \mathrm{~m}^{3}(117.5$ $\left.\mathrm{ft}^{3}\right)$.

The average dose rate of one LTA baseplate /thimble plug waste assembly unshielded is $13,000 \mathrm{rem} / \mathrm{hr} @ 5 \mathrm{~cm}$ from the surface and 1,400 rem/hr@30 cm from the surface.

This assumes there are 16 thimble plugs in the waste assembly. The average dose rate of one production waste assembly unshielded is $6,800 \mathrm{rem} / \mathrm{hr} @ 5 \mathrm{~cm}$ from the surface and $790 \mathrm{rem} / \mathrm{hr} @ 30 \mathrm{~cm}$ from the surface. This assumes there are 8 thimble plugs in the waste assembly. ${ }^{2}$

The average dose rates for the four LTA waste assemblies stacked in a 14" schedule 160 stainless steel pipe is $2,000 \mathrm{rem} / \mathrm{hr} @ 5 \mathrm{~cm}$ and $740 \mathrm{rem} / \mathrm{hr} @ 30 \mathrm{~cm}$ from the side surface of the pipe. For the production waste assemblies, the average dose rates for four assemblies stacked in the 14" pipe is $1,100 \mathrm{rem} / \mathrm{hr} @ 5 \mathrm{~cm}$ and $420 \mathrm{rem} / \mathrm{hr} @ 30 \mathrm{~cm}$ from the side surface of the pipe. Dose rates at other distances from the surface are included in calculation ESH-HPT-98-0316. ${ }^{2}$

Cobalt-60 is the principal contributor of the source term for the stainless steel baseplate/thimble assembly. The average cobalt concentration is estimated to be 122,000 $\mathrm{Ci} / \mathrm{m}^{3}$. The source term will vary between baseplates and will be somewhat dependent on the reactor(s) used. The concentrations in the table below are averaged over the baseplate/thimble plug volume and is for worst case where the assembly will have 16 thimble plugs such as the LTAs. ${ }^{3}$

\begin{tabular}{ccc}
\hline Radionuclide & Ci/ baseplate & Estimated Concentration $\left(\mathrm{Ci} / \mathrm{m}^{3}\right)$ \\
\hline $\mathrm{C}-14$ & 0.01 & 19 \\
$\mathrm{Ni}-59$ & 0.04 & 86 \\
$\mathrm{Ni}-63$ & 4.9 & 9,400 \\
$\mathrm{Nb}-94$ & $1.0 \times 10^{-4}$ & 0.2 \\
$\mathrm{Tc}-99$ & $2.6 \times 10^{-5}$ & 0.05 \\
$\mathrm{Co}-60$ & 63 & 122,000 \\
\hline
\end{tabular}

The four LTA baseplate/thimble plug assemblies will have a total curie content for the Co-60 of 252 curies. The maximum number of production baseplate/thimble plug assemblies that can be placed in the ILTV silos is 19 , assuming the waste assemblies remain assembled as shown in Figure 1. The total curie content of the 19 production assemblies is 1197 curies. The curie content for the Co-60 is well below the $1.910 \times 10^{5}$ $\mathrm{Ci} /$ silo limit of the 1S Manual. The 1S Manual has no limit for Ni-63 curie content. 


\section{Waste Minimization}

Waste minimization of the CLWR irradiated hardware is a concern to the SWD. If the waste is disposed of in the configuration shown in Figure 1, only a small number of baseplate/thimble plug assemblies (19) can be placed in each ILTV silo. Approximately 13 silos will be filled per year with the production irradiated hardware waste. The CLWR Program will continue to look for cost effective ways to reduce the production disposal volume by methods such as disassembling the thimble plugs and the upper head injection cup from the baseplate.

\section{Nuclear Safety, Physical, and Chemical Criteria}

The CLWR irradiated hardware waste is not classified and will not contain fissile materials or process materials that could lead to criticality issues. No transuranic (TRU) waste will be present. Therefore, the CLWR irradiated hardware does not meet the criterion for the minimum reportable quantity (MRQ) of fissile material. No high level waste will be generated from processing the assemblies.' The CLWR irradiated waste will consist of solid LLW only.

Tritium, a radioactive isotope of hydrogen will be contained in the TPBARs. The baseplate/thimble plug assemblies may have trace amounts of tritium on the irradiated hardware. This is true for both the LTAs and production assemblies.

The CLWR waste stream will contain no hazardous waste as designated by the South Carolina Hazardous Waste Management Regulation. The waste material is not be capable of generating toxic gases, combustible gases, vapors or fumes harmful to persons handling, transporting, or disposing of the waste. ${ }^{1}$ Since the waste is not capable of generating off-gases, the disposal container will not become pressurized and will not require venting. The waste will have no pyrophoric materials nor materials capable of detonation or explosive decomposition. Chelating or complex agents such as hydroxylcarboxylic acids, and polycarboxylic acids will not be included in the CLWR irradiated waste. The waste will not contain waste forms containing liquid or materials that could react or degrade the disposal container physically or chemically.

\section{SWD Waste Disposal Requirements}

The CLWR waste generator(s) will follow the requirements for administrative control in accordance with the WSRC 1S Savannah River Site Waste Acceptance Criteria Manual. ${ }^{8}$ The CLWR waste generator(s) will submit a disposal forecast to SWD for forecasted shipments for the coming year. At a minimum, the forecast will include:

- type of waste

- estimated total curies

- estimated total volume

- estimated total mass 
- estimated quantity of containers to be shipped

- potential for deviation requests

All waste shipments from the offsite generator(s) shall be pre-approved by the SWD and accompanied by an open shipping manifest. The manifest shall be signed and dated by the Generator(s) Certification Official and the transport driver. The manifest shall be completed per the 1S Manual.

The CLWR irradiated waste will comply with the following prerequisite program of the WSRC 1S Savannah River Site Waste Acceptance Criteria Manual prior to shipment to SRS:

- Waste Characterization

- Waste Minimization

- Waste Certification

The CLWR waste generator(s) will comply with the following criteria for disposal of the irradiated waste:

- Physical/Chemical Form

- Radionuclide Content

- Nuclear Safety

- Waste Packaging

- Labeling and marking

- Transportation Shipping Cask

- Administrative Controls

If any of the above criteria cannot be met, a deviation request will be submitted to the SWD by the generator(s) in accordance with WAC 5.01 procedure of the WSRC 1S Savannah River Site Waste Acceptance Criteria Manual.

\section{Disposal Container \& Transportation Cask Criteria}

Generator(s) will have an approved disposal container prior to shipment of waste to the SWD. Uncontainerized waste will not be accepted for disposal at the SWD. All nonapproved containers must be approved by SWD before shipment. Disposal containers are approved via the Container Approval Request Form (OSR-29-57) and Instructions found in the 1S Manual, Appendix A-16. Design criteria of the disposal containers shall meet the requirements of the 1S Manual. Lead and other RCRA hazardous constituents shall not be used in fabrication of the container. There are no labeling requirements by SWD on labeling the disposal container. However, offsite generators shall comply with Department of Transportation (DOT) requirements for transferable contamination and DOT labeling requirements. 
There are no specific requirements by SWD on the transportation cask other than the maximum weight for any waste package shall not exceed 50 tons. Offsite generators shall comply with DOT labeling and transferable contamination requirements.

\section{Deviations To The Waste Acceptance Criteria}

Request for deviation from the 1S Manual will be made to the SWD if the CLWR waste generator(s) cannot comply with a specific waste acceptance criteria, certification requirement, or when a requirement is not applicable. The 1S Manual, Procedure 5.01, Waste Acceptance Criteria Deviations, provides specific guidance for requesting deviations to the WAC requirements specified in the 1S Manual. It applies to generators at offsite DOE weapons complex facilities, which have authorization to ship waste to SRS for disposal, as directed by DOE.

\section{Conclusions}

- Total irradiated hardware waste volume for the four LTAs is $0.053 \mathrm{~m}^{3}\left(1.88 \mathrm{ft}^{3}\right)$. The waste will be shipped to the Solid Waste Division (SWD) at SRS from Argonne National Lab West (ANL-W).

- Total maximum irradiated hardware waste volume per year for the CLWR production program is $3.3 \mathrm{~m}^{3}\left(117.5 \mathrm{ft}^{3}\right)$. The waste will be shipped to the SWD at SRS from the production reactor(s).

- Cobalt-60 is the principal contributor of the source term for the baseplate/thimble plug assembly. The average cobalt concentration is estimated to be $63 \mathrm{Ci} /$ baseplate.

- The average dose rate of one LTA baseplate/thimble plug assembly unshielded is $13,000 \mathrm{rem} / \mathrm{hr} @ 5 \mathrm{~cm}$ from the surface and 1,400 rem $/ \mathrm{hr} @ 30 \mathrm{~cm}$ from the surface.

- The average dose rate of one production baseplate/thimble plug assembly unshielded is 6,800 rem/hr@ $9 \mathrm{~cm}$ from the surface and $790 \mathrm{rem} / \mathrm{hr} @ 30 \mathrm{~cm}$ from the surface.

- The CLWR irradiated hardware waste will only have trace quantities of tritium and the radiological concentrations are below the limit of the waste acceptance criteria (WAC) of the 1S Manual.

- The waste meets the requirements of the WAC 1S Manual for disposal in the E-Area Intermediate Level Tritium Vaults (ILTV) at SRS's SWD.

- Irradiated hardware disposal volume could be reduced if the thimble plugs and the upper head injection cup are disassembled from the baseplate.

\section{Reference}

1. Hsu, RH, CLWR-TEF Process Waste Assessment, WSRC-TR-96-0294, Savannah River Site, Aiken, South Carolina

2. Rosenberger, K.H., Calculation of Expected Dose Rates TPBAR Holddown/Thimble Plug Assemblies, ESH-HPT-98-0316, Savannah River Site, Aiken, South Carolina 
3. Sevigny, GJ, Letter to Brizes W, Response To "Information Needs To Support The Tritium Extraction Facility", September 25, 1997

4. King, PJ, CLWR-TEF TPBAR Acceptance Criteria, M-TRT-H-00006, Savannah River Site, Aiken, South Carolina

5. US DOE Chicago Operations Office, Request for Proposal for Lead Test Assembly (LTA) Shipping Cask and Transportation Services, No. DE-RP02-97DP00424, November 12, 1997.

6. Migliore, RJ, Source Terms For The LTA Hold-Down Assembly, TTQP-1-084 Rev. 0. Pacific Northwest Laboratory, Richland, Washington, March 20, 1998

7. Migliore, RJ, LTA Waste Classification Tritium Target Qualification Project, TTQP-1-049 Rev. 0. Pacific Northwest Laboratory, Richland, Washington, June 25, 1997

8. WSRC 1S Savannah River Site Waste Acceptance Criteria Manual

- 2.02 Procedure, Rev. 1, LLW Characterization Requirements, November 3, 1997

- 3.17 Procedure, Interim, Rev.1, LLW Waste Acceptance Criteria, September 30,1997

- 5.01 Procedure, Rev. 1, Waste Acceptance Criteria Deviations, July 25, 1997

- WAC-OG 1 Procedure, Rev 0, E-Area Vaults Low Level Radioactive Solid WAC For Navel Reactor Generators, June 21, 1996

- Appendix A-16,Container Approval Request Form and Instructions, (OSR 2957)

- Appendix A-17, LLW Stream Characterization Form Instructions, (OSR 2982)

- Appendix A-9, Request/Approval For Deviation To SRS Waste Acceptance Criteria Manual, (OSR 29-41) 